\title{
English Learning Motivation and Learning Practices in Indonesian Primary School Context: Parent and Teacher Perspectives
}

\author{
Sahiruddin ${ }^{1}$, Yana Shanti Manipuspika ${ }^{2}$ \\ \{shrdn@ub.ac.id ${ }^{1}$,yana_shanti@ub.ac.id $\left.{ }^{2}\right\}$ \\ Universitas Brawijaya, Indonesia ${ }^{1,2}$
}

\begin{abstract}
This present study explores parents' motivation in having their children enrolled at international school or bilingual school and teachers or educators' motivation in providing English as the medium of instruction in the school. In addition, this study also examines the ecology that parents $(n=14)$ and teachers $(n=26)$ provide for children to develop their L2 proficiency (both at home and at school). This study is rooted in the framework of qualitative research. Moreover, the data were taken from online asynchronous computed mediated interview using structured-interview. Interview items for parents and teachers is adapted from Gardner's [1] Attitude Motivation Test Battery (AMTB) and from Dewi [2]. Interview data were analyzed based thematic analysis, looking at the emerging themes from data. This study revealed that parents' motivations for enrolling children in bilingual or international school were more integrative than instrumental. English as a lingua franca within the context of multicultural world has motivated parents and teachers to introduce English at the early education. Bilingual approach was found effective in English delivery system for social and cultural consideration. As part of the efforts of responding to the digital era, both parents and teachers bring multimodal sources (technology-based sources) in enhancing English learning.
\end{abstract}

Keywords: Multicultural, Bilingual, English as Medium of Instruction (EMI), L2 Proficiency, Motivation

\section{Introduction}

English has been widely acknowledged as an international language or lingua franca that majority of people around the world use to communicate across countries. Within multilingual and multicultural realities nowadays, English mediates people across the globe to communicate each other. In Indonesian context, the fundamental importance of English mastery has driven Indonesian government to issue educational policy where English is the first main foreign language taught as a compulsory subject in school since Indonesia's independence in 1945 [3]. To respond to global competitiveness, Indonesian government in 2003 issued the frameworks and guideline through National Education System Law No. 20 of 2003 as to encourage top schools to upgrade its status for international standard school (ISS) where English was a medium of instruction for all subjects taught in classroom. People appreciated the regulation designated along with the demand of learning English, although the regulation was ceased in 2013 due to the decision of Constitutional Court with the consideration that international standard school brought threat to national identities. Although the new 2013 curriculum to some degree reduce 
allotted hours for English subject, the attention put by people and school to the need of learning English for Indonesian young learners continues.

The demand of learning English is increasing particularly with the presence of international companies in Indonesia where the employee is required to be able to speak English. As a result, English is not only taught by the formal institution such as school but also by the informal institution such as a community learning group or a tutoring institution. The emergence of the demand of learning English in Indonesia can also be seen from the evidence that some schools for early education level like kindergarten and elementary schools start introducing English as the subject of learning. Even, many schools starting from primary schools to high school offer international class program or declare themselves to be international standard schools where English as the medium of instruction (EMI) in classroom. In 2018, there were 198 international schools in Indonesia, and Indonesia was ranked to be the country with the highest number of international schools, followed by Thailand (192) Malaysia (187), Singapore (119) and Vietnam (118) [4].

Responding to this phenomenon, Manara [5] examined English teachers' perception about the position of English and Indonesian language revealing that eighteen participants share a common perception that English provides access to globalization, and learning English is expected to assist them to compete internationally. However, she found that although the dynamic interaction occurs between English, Bahasa Indonesia and globalization, the fear of losing Indonesian language as containing social and local identities needs to be our concerns. The commodification of English has raised its prestige bringing about to being perceived as higher and more superior than Indonesian language.

Albeit the cease of ISS in Indonesia, many private schools offering English as a medium of instruction were growing in numbers with the name of "international" school, bilingual school, or national plus school [5]. This indicates that both parents and school administrators share the common perception of the need of providing students with English as a medium of instruction. On the other words, English still becomes the highly sought commodity in Indonesia. The use of English as medium of instruction has also been argued to be related to access to good education and employment [6]. This paper argues that English has been regarded as importance for students nowadays since the globe becomes borderless as a result of information and communication technology (ICT) where everyone can communicate across the globe through online platform and physical contacts in multicultural worlds. Within this context, this study explores parents-children's motivation in studying at international school or EMIbased schools and teachers or educators' motivation in providing English as the main instruction in the school. Primary schools are chosen in this study as the research in this context has been inconclusive regarding the need of introducing English in the early age or focusing more on national and indigenous languages. Insights from both parents and educators will provide better understanding about this issue. In addition to motivation, this study also investigates the efforts or practices designed by both parents and schools/ educators in facilitating the development of English proficiency. This study is worth conducting to provide an insight of how parents and educators perceive the role of English in local and global context within multilingual and multicultural contexts, and the efforts or best practices of the ecology of L2 learning made to facilitate their students or children English developments. The issue of intercultural competence by learners enrolled in this international school is also elicited implicitly.

The research questions are formulated as follow: 1) What are the parents' motivations to have children enrolled in international or bilingual school? 2) What are the teachers' perceptions about how English should be taught in international or bilingual school? 3) What are the efforts made by parents and schools to facilitate the development of L2 proficiency? 


\section{Research Method}

This study is rooted in the framework of the combination between qualitative and quantitative research. It is qualitative since this research aims to understand the "complexity" of the data (interview) through interpretation and reflection to establish the meaning [7]. Moreover, this research concerns with using data sources to collect "thick description" [7]; thus, the data were analyzed into narrative description, interpretation and textual. In addition, as to support the qualitative data, this study is quantitative particularly descriptive quantitative in a way that the data collected involved questionnaire data.

This study involved parents and teachers or educators from bilingual or international schools in Malang. International schools are defined as schools which implement English-only policy in the classroom, while bilingual schools refer to school which implement bilingual approach in teaching English.

Questionnaire and interview are the main instrument chosen to collect the data. The questionnaires deal with the general information regarding the perception of parents and teachers about the role of English and what are the practices designed to facilitate the presence of English ecology. Questionnaire for parents is adapted from Gardner's [1] Attitude Motivation Test Battery (AMTB), and interview questions are adapted from Dewi [2].

Purposive sampling is employed in data collection. The criteria to be met for participants involves teachers and parents at fourth grade from international school or bilingual school. Fourteen parents $(n=14)$ and twenty-six teachers $(n=26)$ involved in online asynchronous computed mediated interview using structured-interview [8]. The data collected were about the teachers' attitude and teaching practices in supporting English learning development for children at schools.

After the responses are collected, they are analyzed in terms of the motivation of parents and teachers in introducing English for their children or students, the efforts they have applied in facilitating their English development. Data are inductively analyzed based on the theme emerged from the data for interview data, and survey data are descriptively computed in terms of percentage.

\section{Findings and Discussion}

This study scrutinizes the parents' motivations to have their children enrolled in bilingual or international school, the teachers' perceptions about how English should be taught in EMIbased school, and the efforts made by parents and schools to facilitate the development of L2 proficiency.

\subsection{The Parents' Motivations to have their Children Enrolled in Bilingual or International School}

Fourteen parents $(n=14)$ involved in this study consisting $64 \%$ from international class program and $36 \%$ from bilingual class program.

Regarding the first concern of this study about parents' motivation to have their children registered in bilingual or international program, this study revealed that there were several reasons for parents to have their children enrolled in bilingual or international program. In this paper, parents' goals were clustered based on theme to avoid repetition and overlapping. Their 
goals were to provide a conducive environment for English skill development, to communicate using English with other students and to maintain their acquired English, to be competent users of English, to have more flexible learning system provided by school, to have a wider knowledge of the world, to equip children with adaptive character when dealing with Englishspeaking people and Indonesian people, to provide children with English learning from the early education, and to make children become competent users of two languages, Indonesia and English.

In addition, other reasons declared for choosing the schools were that $50 \%$ parents assumed facilities and programs in bilingual or international schools were better off than other regular schools, and 14\% parents believed that schools support and facilitate children's talents and skills, while the rest informed that schools provided convenient environment for learning, and had more qualified teachers.

Beyond this motivation, the fundamental thing to investigate from parents' perspective is their attitude about the importance of English learning for their children. This study found that parents found English was perceived playing an essential role in children life for several reasons. First, English was considered as an international language or lingua franca in this global and multilingual era so that the ability to master or use English was fundamental. Second, learning English would make children understand and get more knowledge from many parts of the world and to know the other cultures across the globe (intercultural competence perspective). Third, English as an international language needs to be learned for future active role in international level. Fourth, digital-based information particularly in social media was mainly in English so that English mastery played an essential role. Children can further express their English in social media as well. Fifth, English will be used in daily communication in Indonesia in the future (bilingual or mixed language). Sixth, English will play a key role in the future especially for global information literacy exchange, including scientific exchange. They can get contact with other people across the world through the use of information and communication technology (ICT).

Furthermore, in relation to the parental efforts in facilitating the development of English learning at home this study demonstrated that parents provided some supports for English learning development including using English for communication at home, providing English books, learning and practicing pronunciation and speaking, providing internet and online English TV channel subscription as well as access to YouTube, and accompanying reading English stories. Most parents confirmed that they used English for daily communication to some degree with their children, and some confirmed using English occasionally. This suggests that most parents are able to communicate in English with their children. All this information only illustrated how English supports are given at home.

In addition, 28\% parents confirmed that they provide English books, 21\% parents provide an access to online English TV channels. 7\% parents mentioned they did not let their children to get enrolled in English course. The rest of parents declared they facilitated children's English development through online games, English books, YouTube, and practice of using English for communication.

Among the issue of introducing second language at the early age is how parents facilitate their children's mother tongue (first language). This study also examines how local language is developed and facilitated by parents. The study found that parents used both local language and English at home, and that local language is also supported by social surrounding and extended family.

As set out above this study demonstrated several efforts and practices at home for children. In terms of parental supports outside home, this study found that only 3 out of 14 parents 
facilitated English course for their children. Meanwhile, the other parents provided some supports, such as joining English competition including story-writing and story-telling and encouraging to have a videocall or communication with their peers in English. This suggests that parents felt that English learning at school and at home were sufficient enough to facilitate the development of English.

This study also examined parents' perception about the programs and practices of English development at school. This study found that parents to some degree felt satisfied with the schools' programs as indexed by the use of English as the primary language used at school, interactive teaching and learning methods in facilitating children's talent and English skills, and qualified teachers. However, some suggestions were made for school including the need for more active discussion at class and more conducive environment which could push the children to use English at school without any social and cultural burden.

In addition, parents mentioned some suggestions which could be taken into account by school for better improvement. Those covered the need for more English native speakers, condition or environment that set up natural English conversation, teacher training to make teachers more active users of English, more programs of collaboration among international schools, programs for establishing self-confidence for children in using English, clear English hours, more conversation or speaking hours, and more projects encouraging global awareness.

\subsection{Teachers' Experiences in Developing English Teaching and Learning Practices in Bilingual or International School}

Twenty-six teachers $(n=26)$ from bilingual and international schools participated in this study. They were from different grades including $27 \%$ from grade 4 , then $23 \%$ from grade 6 , $19 \%$ from grade $5,15 \%$ from grade 3 and the rest were from grade $1-2$. Teachers' qualification was undergraduate degree $(96 \%)$ and graduate degree $(4 \%)$. They had an average of 7 years teaching experience. The teachers were $73 \%$ from bilingual program and $27 \%$ from international program/school. They involved in online asynchronous computed mediated interview using structured-interview. The data collected were about the teachers' attitude and teaching practices in supporting English learning development for children at schools.

This study revealed that the motivations driving teachers to teach English at either bilingual or international class program were to develop English communication skills, to have global and multicultural insight or knowledge, to prepare for future career requiring the use of English at this global era, to prepare children in the global competition, to equip learners with the skills and knowledge needed for higher education level particularly at overseas education level in the future (intercultural competence), to make students updated with any news across the world (global competence), and institutional duty to implement English as the institution has a joint collaboration with international education institution such as Cambridge.

In addition, teachers also showed some points of the importance of introducing English at the early education level and in the future of the children's life. They involve the evidence that Indonesia has been one of favorite tourist destinations, developing English and mother tongue, English as lingua franca as a language needed for education and workplace purposes, the belief that language learning can be fully developed at the early ages, also most information in digital technology including social media available in English.

Regarding structured teaching and learning activities or practices applied at schools in order to develop students' English learning development, teachers illustrated some efforts and programs. First, the time allotment for English subject 3 times a week, implementing national and international curriculum at school, English as medium of instruction in instructional 
process, encouraging students and all teachers to communicate in English on daily basis, conversation lesson, active annual participation in Global Youth Summit, one-hour play and song in English in every month, hiring native speakers, conducting English campaign, Cambridge test, and conversation, the use of English everyday obliged to every person at school, conversation class with native speakers weekly, English day, and subjects other than English taught in bilingual with English references (Content-language integrated learning/CLIL).

Teachers also made some efforts to maintain and develop English development outside schools. The supporting activities include assignment or homework, projects to interview in English, handout/ worksheet to do, recommendation to join English courses, encouraging to use English through social media, teacher-student communication using English via telephone or electronic communication, English communication practice with parents, and providing some links to watch at home to independently develop students' English skills.

This study also found that teachers believed that the children's English development was best supported by the collaboration between teachers and parents. Some suggestions made by teachers for parents were practicing English with the child, providing access to English video or movie, providing gadget and access to internet allowing children to develop their English using online resource and applications, getting children enrolled English courses.

\subsection{The Efforts Made by Parents and Schools to Facilitate the Development of L2 Proficiency}

In this pandemic situation, some challenges in teaching English were also described by teachers. They involved the limited access to monitor students' progress, particularly speaking skills, lack of innovative teaching which motivating students in online learning, lack of students' understanding toward materials, limited time to interact with students through video call to every student, low bandwidth internet connection interfering the clarity of instruction which in turn avoiding understanding and comprehension, and lack of English conversation practices through online platform. One of the responses was "during this pandemic, students are asked to read stories and watch shows in English and then to give feedback. Challenges: making a lesson plan that can increase students' creativity and minimize boredom in learning English that they have to do online".

\subsection{Discussion}

Multilingualism and multiculturalism become the norm in this multilingual and multicultural world. Within this regard, the need to learn English as a lingua franca or language acceptable across the globe for communication or cultural exchange has been widely acknowledged. This study explores parents' motivations for enrolling their children in bilingual or international school where English becomes the medium of instruction (EMI). This study found that parents' motivation includes providing a conducive and supportive environment for English learning and use from the early ages, facilitating children to be competent at two languages (Indonesia and English), maintaining the acquired English, and developing children's adaptive character and global competence. Those motivations demonstrate that parents are aware that English mastery is substantial in children life. In addition, they also mention their belief that English has now been acknowledged as an international language or lingua franca where information sources are now delivered in English and people from any part of the world accept English as a means for communication, and that to win to global competition children are required to be proficient in English besides to be multiculturally competent. 
Although the motivations by parents above have an indirect effect on children's learning, parents' motivation will lead to their best efforts to facilitate children's learning success. In other words, parents' motivation will indirectly influence children's motivation in learning English. As theoretically explained, motivation is one of the factors contributing to the success of language learning success [9][10]. Motivation, according to Troike [10], is the desire to attain the goal. It is a kind of strong desire to learn something and thus becomes the key factor that encourages the learners to keep active to achieve the desired target. As Dornyei [11] stated motivation has been widely accepted by both teachers and researcher as one of the key factors that influences the rate and success of second or foreign language learning. Instrumental Motivation is the learners' interest in learning a language for getting essential qualifications and improving career prospects. Meanwhile, integrative Motivation is the learners' desire to learn a language so that they can communicate with confidence with a speaking community [1].

Looking at the overall motivation described by parents, parents' motivations to children in learning English are more integrative than instrumental in nature because they did not mention specific goal and period in enrolling their children in English-instructed schools. Empirical previous evidence reveals that Indonesian L2 learners, according to some previous studies are more integrative in the literacy factors, for the example, when they learn vocabulary from reading English book, listening to and watching English songs and movies, playing the game [12]. However, in East Asian setting motivation is more instrumental to meet social and parental expectation [13]. The difference of the finding may be explained from variability of the participants, for instance parent-children vs. university students.

This study reveals that parents and school teachers share the same perception about the importance of English in this global era. English was considered as an international language or lingua franca in this global era so that the ability to master or use English was fundamental, and that learning English would make children understand and get more knowledge from many parts of the world. They can also learn other cultures from other countries. This notion is known as intercultural competence). This finding confirms previous study that parents and school administrators share the common perception of the need of providing students with English as a medium of instruction [5].

Parents and teachers also expect that their children or students can later have a competence required for global competition, such as intercultural and global competence. The schools want to prepare the learners to be able to compete internationally in the future. This result is in line with the evidence that some education institution from elementary school and high school offer English instruction, arguing that it is relevant to people or local aspiration to give children or learners competitive language skills to compete in the global world in their future [14]. However, the context of the schools in this study that provide English as a medium of instruction has been a trend that many primary schools have decided to drop indigenous languages replacing them with English subject [15].

Despite the motivation to teach or learn English for early education, there is an issue about the development of local language or Bahasa Indonesia. It is assumed that learning English from the early age will hamper the acquisition and development of mother tongue or local language. Within this concern of the need to maintain and develop local language, it has been recommended that for ASEAN countries, involving Indonesia should postpone English at primary education to provide space for indigenous languages [16]. Responding to this issue, this study reveals that parents and teachers did not neglect the use of first language at home or schools. They use both local language and second language for their daily communication practices. Bilingual approach is the option that both parents and teachers take as the best option for English learning at the early education. Furthermore, Kirkpatrick's idea is further developed 
in a way that learning other languages and other cultures are also essential. Besides learning English and local cultures, it is also recommended that Indonesian learners are equipped with ASEAN cultures [17].

Furthermore, this study found that the use of English and Indonesia as bilingual approach has been used at home and school in this study. English-only approach or monolingual approach has not been found effective in teaching and learning English for children in this study. They mention about 40-50 of using English-Indonesia in their English learning and communication. This seems reasonable for some constraints found, such as children's local language and English on the progress, less English proficient for some parents and teachers (particularly for nonEnglish teachers) and other related factors. Beside bilingual approach, thus study also demonstrates that teachers apply Content-language integrated learning/CLIL in teaching English, particularly for subjects other than English, and they considered this approach to be a good option in developing L2 proficiency.

The use of multimodal resources (books, audio, visual and video) in enhancing English learning and communication reflects the awareness of parents and teachers in terms of the use and advantages of incorporating technology in language learning nowadays. This attitude should be positively maximized in the era of digital disruption where sources of learning can be from online sources involving many multimodal literacy resources. The availability of digital-based information particularly in social media and global information literacy exchange should be introduced to children on parents' and teachers' guidance.

\section{Conclusion}

This present study has revealed that parents have their children enrolled in either bilingual or international schools for some reasons. First, they want to see their children motivated to learn English since elementary level of education. This is due to the fact that practice makes perfect. Next, parents found English has an essential role in children life since it is considered as an international language or lingua franca in this multilingual and multicultural world so that the ability to master or use English is fundamental. In addition, digital-based information such as in social media is mainly in English so that English mastery plays an essential role. Regarding teacher's perception about how English should be taught in EMI-based school, some responses can be drawn. Implementing both national and international curriculum at school, using English as medium of instruction in teaching process, encouraging students and all teachers to communicate in English on daily basis are considered as efforts to expose students to English. Recommendation is addressed to future researchers, in which further study should address the issue of students' perception in learning English: advantages and challenges from different levels of education from elementary, secondary and highs school levels.

\section{References}

[1] R. C. Gardner, R. N. Lalonde, and R. Moorcroft, "The role of attitudes and motivation in second language learning: Correlational and experimental considerations," Lang. Learn., vol. 35, no. 2, pp. 207-227, 1985.

[2] D. Fitriasari and B. Suzanto, "Pengaruh Motivasi Kerja, Disiplin Kerja dan Koordinasi terhadap Kinerja Pegawai (suatu Studi pada Cabang Pelayanan Dinas Pendapatan Daerah Provinsi Wilayah Kota Bandung III Soekarno Hatta)," J. Ekon. Bisnis Entrep., vol. 8, no. 2, p. 41351, 2014.

[3] S. Dardjowidjojo, Rampai bahasa, pendidikan, dan budaya: kumpulan esai Soenjono 
Dardjowidjojo. Yayasan Obor Indonesia, 2003.

[4] Nugraheni, "Jumlah sekolah internasional terus bertambah," Dream, 2018. [Online]. Available: https://parenting.dream.co.id/diy/jumlah-sekolah-internasional-di-indonesia-terus-bertambah1808131.html.

[5] C. Manara, "That's what worries me: Tensions in English language education in today's Indonesia," Int. J. Innov. English Lang. Teach. Res., vol. 3, no. 1, pp. 21-35, 2014.

[6] R. Rubdy, "Reclaiming the local in teaching EIL," Lang. Intercult. Commun., vol. 9, no. 3, pp. 156-174, 2009.

[7] L. Kervin, W. Vialle, J. Herrington, and T. Okely, Research for educators. Thomson. Social Science Press, 2006.

[8] W. Gibson and A. Brown, Working with qualitative data. Sage, 2009.

[9] S. M. Gass and A. Mackey, The Routledge handbook of second language acquisition. Routledge, 2013.

[10] M. Saville-Troike and K. Barto, Introducing second language acquisition. Cambridge University Press, 2016.

[11] Z. Dörnyei, "Motivation and motivating in the foreign language classroom," Mod. Lang. J., vol. 78, no. 3, pp. 273-284, 1994.

[12] P. Patahuddin, S. Syawal, and S. Z. Bin-Tahir, "Investigating Indonesian EFL learners' learning and acquiring English vocabulary," Int. J. English Linguist., vol. 7, no. 4, pp. 128-137, 2017.

[13] C. A. Warden and H. J. Lin, "Existence of integrative motivation in an Asian EFL setting," Foreign Lang. Ann., vol. 33, no. 5, pp. 535-545, 2000.

[14] M. S. Zein, "Elementary English education in Indonesia: Policy developments, current practices, and future prospects," English Today, vol. 33, no. 1, p. 53, 2017.

[15] N. Hadisantosa, Learning through English: policies, challenges and prospects: insights from East Asia. British Council, 2010.

[16] A. Kirkpatrick, "English as an international language in Asia: Implications for language education," in English as an international language in Asia: Implications for language education, Springer, 2012, pp. 29-44.

[17] A. Kirkpatrick, "English in ASEAN: Implications for regional multilingualism," J. Multiling. Multicult. Dev., vol. 33, no. 4, pp. 331-344, 2012. 